\title{
STUDENTS' ADAPTABILITY IN ONLINE LEARNING BASED ON MALAYSIAN STUDENTS' PERCEPTION
}

\author{
ATEERAH ABDUL RAZAK*, NOOR HISHAM MD NAWI, ASMA’ LAILEE MOHD \\ NOOR, BURHAN CHE DAUD \& MARWAN ISMAIL
}

\begin{abstract}
The education field has undergone a new norm due to the pandemic of COVID-19 and it can be seen that new techniques and improvements can be applied among the educators and students. In a Malaysian context, it is revealed that a majority of universities have enhanced the quality of teaching via online platforms such as Cisco Webex, Google Meet, Zoom and many more that provide the medium for instructional delivery. However, it is also imperative to view the situation from the students' perspectives in order to identify the issues that have occurred throughout the online learning process. The current study is conducted to identify the level of adaptability among students towards online learning and it consists of several components such as physical, spiritual, and emotional aspects. The respondents were selected through purposive sampling from selected local universities in Malaysia where about 316 students participated. This study was done quantitatively, and the results were analysed using Smart PLS 3.2.8. The findings showed that there were high values of Cronbach alpha and composite reliability which indicates that students agreed with the items in all the constructs in terms of physical $(\alpha=0.879, C R=0.906)$, spiritual $(\alpha=0.863, C R=0.901)$, emotional $(\alpha=0.953, C R=0.961)$ and adaptability $(\alpha=0.913, C R=0.931)$. The validity (AVE) of all the constructs were also in the acceptable range. It reveals that the physical, spiritual, and emotional components are imperative in order to ensure students could adapt with the new norm of online learning during the pandemic of COVID-19. Other than that, it shows that a balance well-being could hinder problems related to tough learning situation especially in online learning.
\end{abstract}

Keywords: Online learning; Malaysian student, Well-being, Pandemic, Adaptability

\section{INTRODUCTION}

\section{Online Learning During the Pandemic of Covid-19}

Learning involves the process of teaching and learning implementation and usually, it is conducted in the classroom. It consists of communication activity among teachers and learners in order to deliver and achieve a learning goal (Ety 2015). The pandemic of COVID-19 has affected people around the world, and this necessitates humans to adapt with the new norm. The current study analyses how students prepare themselves with new norm learning or 'panicgogy' (Anya 2020). A recent related study of online learning has been conducted to identify the strengths and weaknesses among learners and students, in the hopes that education quality could be improved.

One such study looked into to the perspectives of Pakistani higher education learners of digital learning during the pandemic of COVID-19. It revealed that online learning hinders the excellent productivity in the underdeveloped country. This is due to the fact that they had 
to face technical and also financial issues (Kainat \& Muhammad 2020). It could be understood that external support is integral to ensure that students are able to participate well in the learning process. This would seem that students must have a good preparation before starting class and have a favourable plan to avoid any problems during the online class.

Another research related to remote teaching and learning in Canada identifies several solutions that need to be highlighted through government policies regarding online learning during the pandemic of COVID-19. It suggests that there is a requirement for equity consideration, on behalf of parents and teachers. This might be because several of them reside in areas that possess limited data coverage which would become an obstacle for quality learning. Furthermore, the social and emotional effect on students is also necessary to be taken into account since life changes trigger numerous difficulties among affected people around the world (Timmons et al. 2021).

\section{METHODOLOGY}

The current study has been conducted to evaluate how students adapt with online learning, especially during the pandemic of COVID-19. It was organised in June 2021 and participants consist of 14 public universities in Malaysia such as Universiti Malaysia Kelantan (UMK), Universiti Malaysia Pahang (UMP), Universiti Malaysia Perlis (UNIMAP), Universiti Malaysia Sabah (UMS), Universiti Malaysia Sarawak (UniMAS), Universiti Malaysia Terengganu (UMT), Universiti Pendidikan Sultan Idris (UPSI), Universiti Putra Malaysia (UPM), Universiti Pertahanan Nasional Malaysia (UPNM), Universiti Sains Islam Malaysia (USIM), Universiti Sultan Zainal Abidin (UNISZA), Universiti Teknologi Malaysia (UTM), Universiti Teknologi MARA (UITM), and Universiti Utara Malaysia (UUM). The respondents also came from various level of semesters, which is from semester 1 until 8. Additionally, this study applies the purposive sampling method, and it focuses on university students from year one until year four. The constructs that have been developed include physical, spiritual as well as emotional and the components contribute to students' adaptability during online learning. All of the components are measured using 7 Likert scale since it is an appropriate measurement scale. Additionally, using seven Likert scale produce better reliable results rather than 5 Likert scale (Joshi et al. 2015).

Students' adaptability is measured by using the aspects of internal and external values. Internal values mean the inner aspect such as students' motivation, emotion, and spirit to learn virtually. While the external values relate to how students deal with environment such as physical as well as the way they interact with human being. All of the constructs had reached the acceptable values of reliability and validity since it has gone through the analysis process using the Structural Equation Model (SEM). For the physical component, it contains nine items that measure the physical forms that students have for their online learning. While the second factor is the emotional element that is needed during the learning process. It encompasses six items to measure the level of the emotional well-being among students.

The third contributor of students well adapting to online learning is the spiritual aspect and it involves six items that relate to the spiritual measurement for human well-being. For the items that evaluate the students' preparation for online learning, it encompasses internal and external values. The current study also identifies the demographic of respondents in terms of residential area, income background, occupation status of whether or not they are employed in a part time job and other related items that define the background of the students. This is important because the socio-demographic and geographic background of students portrays their well-being. In addition, it could also reveal the perception of learners and share different 
approaches on how they could face online learning during the crisis of COVID-19 (Aleksander et al. 2020).

\section{Development of Physical Aspect}

From the results, it shows that there are several aspects that students apply during online learning. The physical construct consists of items 1; "I get a lot of beneficial information on how to participate in online learning." This item measures the quantity of new knowledge that they gain from online learning. Teachers play an important role to ensure that knowledge can be transmitted during online learning (Indira and Sakshi 2017). Item 2; "I get a lot of skills that were taught by experienced teachers" explores how teachers use their skills to impart knowledge. It is compulsory for educators to apply innovation in education such as optimising teaching methods, as well as additional cooperative and collaborative learning so that it could contribute to the future careers of the students (Enik et al. 2018). Additionally, item 3; "I get to identify that some of the teachers are still practising traditional teaching style" identifies the perception of students towards instructors. It is proven that some educators are reluctant to adapt to the new mode of teaching and they face difficulties to handle online classes. It is mentioned that teachers being unprepared towards digital learning is due to them lacking selfefficacy to carry out the class virtually (Zakaria et al. 2021).

For item 4; "I get the opportunity to explore the guidelines on how to use e-learning tools", highlights the initiative of students to explore e-learning materials. It shows the effort of students, and this is integral to help students understand the content better. Additionally, it is undeniable that students are able to make proper arrangements since online classes are a platform for performing continuous learning (Allan et al. 2021). Whereas item 5; "I get to learn from teachers who are experienced in preparing teaching materials" also reveals the potential among educators in handling online lessons. It is agreed that among the difficulties faced by teachers during online learning are student participation, effort from the students themselves, and also how teachers coordinate the class (Zakaria et al. 2021). This is closely connected with item 6; "I get to learn from teachers who have a lot of skills in conducting online learning." Thus, it is crucial for teachers to join tutorials so that they will become more accustomed to the e-learning system. This is because a previous study has mentioned that in underdeveloped states, educators are not fully capable in utilising online learning (Allan et al. 2021).

Students are also asked about data coverage; "I get good internet data and coverage during online learning" to measure whether or not they face problems with data limitation. This item could evaluate the frequency of having internet problems and this would lead to poor communication between learners and teachers (Allan et al. 2021). Additionally, it is shown that learners in Southeast Asia face great difficulties due to the lack of internet access (Jalli 2020). Similar with the situation in Cambodia, where practitioners in rural areas have insufficient access to internet coverage and could not adapt with the technology advancement (Flynn \& Himel 2020).

Item 8 relates to student preparation prior to participating in online learning; "I get to prepare for a Plan A and B while joining the online activities". It refers to the preparation of students to partake in online learning, thus learners having well-planned preparation is essential in order to obtain a satisfying and effective learning experience (Rapanta et al. 2020). Likewise, students are also asked about financial difficulty; "I am able to subscribe to internet data without any financial issues". A previous study mentions that the financial difficulty experienced among students is caused by the fact that they lack monetary resources and struggle with high living costs (Daud et al. 2018). 


\section{Development of Emotional Aspect}

This construct was developed in order to measure the emotional preparedness of students during online learning. Item 1; "I always find that online learning is very interesting" measures the level of motivation during online learning. This element is compulsory because it could be a contributor to evaluate student engagement in online classes (Mese \& Sevilen 2021). While Item 2 relates to the communication between teachers and students; "I always communicate with the teacher during online learning activities". This attitude should be instilled among students because it will make learning more interactive. It is proven that this activity creates positive correlation of students' commitment with learning material (Cebi \& Guyer 2020).

While item 3; "I always enjoy joining online learning activities" identifies how students find the online lesson. This item could measure the enjoyment among learners, and it could be a motivation booster too (Mese \& Sevilen 2021). It would seem that teachers play an important role to make the class fun and interactive. Meanwhile item 4; "I am always prepared well before joining online learning." This includes several elements such as technical, communication, student attributes and time management. This item assists educators to develop a better design of the course as well as help learners to have better preparation before online learning (Florence et al. 2020).

Item 5 explores whether or not students could solve their problems; "I always solve my problems before attending online classes". This is part of critical thinking, and it cannot be mastered within a short period (Fitarahmawati \& Suhartini 2020). This skill needs to be practiced by students so that they will be wiser in decision making and problem solving. Whereas the last item; "I always have high motivation to attend online classes" evaluates the motivation aspect and the various methods of learning that could encourage students to be more enthusiastic in the learning process (Koçoğlu \& Tekdal 2020).

\section{Development of Spiritual Aspect}

This component has been developed mainly from the validated instrument from Ateerah and Lukman's (2019) findings of the happiness instrument development. Item 1; "I always say my prayers before attending online classes" relates to the spiritual preparation before a lesson. This is one of the virtuous attitudes towards the guidance of individual belief and it is a symbol of religious character (Umi et al. 2021). Whereas item 2 connects to time management in terms of study and religious matter; "I always allocate my time for study time and religious activities". This includes obligatory practices such as the five daily prayers among Muslims. Additionally, religious activity is also part of the evaluation of Islamic character (Zulvia et al. 2020).

Item 3 asks about the perseverance in performing religious routines; "I always perform religious practices consistently." It is also closely related with the aspect of istiqamah (consistency), additionally it is also proven that this attitude contributes to the enhancement of individual performance (Laksmi et al. 2020). For item 4; "I always perform my salah early" refers to the five compulsory daily prayers, and it is an obligation for Muslims. Additionally, it is a formal ritual that leads to the peacefulness of the soul (Abdul Rashid et al. 2020).

For item 5; "I always pray for safety and well-being", identifies how students protect themselves by prayer as well as possessing a firm belief in Allah. By performing prayer, it strengthens tawakkal (reliance) on Allah with anything that happens to them as well as experiencing a calm feeling especially in facing hardship during the pandemic of COVID-19 (Abdul Rashid et al., 2020). While item 6 explores how students cope with difficulties that they have faced; "I always have positive impressions on God's plans for me". This item asks students about the concept of having a good perception or husn zhonn with God's arrangement. 
During the pandemic of COVID-19, it is encouraged to have positive impressions with what God has planned towards His servant. This attitude leads students to be more patient in handling their daily challenges during the pandemic. Allah mentions that $\mathrm{He}$ is as His servant perceive of Him, and He is with him (Al-Bukhari 7405). If students could apply this virtuous character, it will assist them to be more sensible in facing the new norm especially in the context of online learning.

\section{Development of Adaptability Component}

This domain is developed to measure how students adapt in online learning, and the items relate to several aspects. It focuses on the external factors that assist student to adapt well in online learning. For the first item, it investigates how students create bonding with educators; "I form close bond with the teachers during online learning activities". Teachers' role in portraying good value is crucial in obtaining the best adaptability in online learning (Camelia \& Elena 2021). Other than that, item 2 analyses how students' make friends especially during virtual learning; "I get to know many new friends when I participate in online learning activities." This is proven that students can build stronger sense of community among learners particularly during online learning (Tuan 2015).

Thirdly, the third item identifies how students manage their time; "I manage to allocate my time for study and social activities." This aspect is necessary to be explored because previous study states that the problems relate to online learning include insufficient preparation to have a balance social life (Shivangi 2020). While item 4 is based on delegating task; "I manage to complete tasks given by the teachers on time." These items are developed to identify whether or not students could adapt with online activities, and this is in line with the findings of (Nurul \& Fahdian 2020) who mention that students are able to adapt with online activities by utilizing technology especially during the period of IR 4.0. This item also relates with the next item; "I obtain good guidelines in online learning activities." According to Camelia and Elena (2021), students who obtain a proper training from educators will produce the highest result in final exam since students enjoy attending the course.

From the developed constructs, it is understood that students should have several elements to assist them in adapting with the new norm in online learning. Additionally, the items are in line with previous study related to online learning and it is justified that the important components become the factors of students' adaptability in online lesson.

\section{RESULTS}

The current study gathers the demographic profile of students which have been listed in Table 1. The socio-demographic information is necessary to identify students' perception of issues in online learning and how it is influenced by their background (Aleksander et al. 2020). This section elaborates the findings of the current research. It identifies the background information of the students as depicted in Table 1 below:

Table 1. Demographic Information Table.

\begin{tabular}{lcc}
\hline \multicolumn{1}{c}{ Demographic Variable } & $\mathrm{N}$ & $\%$ \\
\hline Gender & & \\
Male & 94 & 29.7 \\
Female & 222 & 70.3 \\
\hline
\end{tabular}

University 


\begin{tabular}{|c|c|c|}
\hline UMK & 124 & 39.2 \\
\hline UMP & 2 & 0.6 \\
\hline UNIMAP & 5 & 1.6 \\
\hline UMS & 1 & 0.3 \\
\hline UniMAS & 1 & 0.3 \\
\hline UMT & 3 & 0.9 \\
\hline UPSI & 6 & 1.9 \\
\hline UPNM & 33 & 10.4 \\
\hline UPM & 9 & 2.8 \\
\hline USIM & 5 & 1.6 \\
\hline UNISZA & 15 & 4.7 \\
\hline UTM & 2 & 0.6 \\
\hline UITM & 49 & 15.5 \\
\hline UUM & 61 & 19.3 \\
\hline \multicolumn{3}{|l|}{ Year of study } \\
\hline One & 197 & 62.3 \\
\hline Two & 65 & 20.6 \\
\hline Three & 38 & 12.0 \\
\hline Four & 16 & 5.1 \\
\hline \multicolumn{3}{|l|}{ SEM } \\
\hline 1 & 102 & 32.3 \\
\hline 2 & 127 & 40.2 \\
\hline 3 & 24 & 7.6 \\
\hline 4 & 23 & 7.3 \\
\hline 5 & 12 & 3.8 \\
\hline 6 & 23 & 7.3 \\
\hline 7 & 3 & 0.9 \\
\hline 8 & 2 & 0.6 \\
\hline \multicolumn{3}{|l|}{ Nationality } \\
\hline Malaysia & 316 & 100.0 \\
\hline \multicolumn{3}{|l|}{ Living Area } \\
\hline Rural & 173 & 54.7 \\
\hline Urban & 143 & 45.3 \\
\hline \multicolumn{3}{|l|}{ Religion } \\
\hline Buddhism & 3 & 0.9 \\
\hline Christianity & 6 & 1.9 \\
\hline Hinduism & 7 & 2.2 \\
\hline Islam & 300 & 94.9 \\
\hline \multicolumn{3}{|l|}{ Age } \\
\hline 18-20 Years Old & 101 & 32.0 \\
\hline 21-25 Years Old & 198 & 62.7 \\
\hline 26-30 Years Old & 17 & 5.4 \\
\hline \multicolumn{3}{|l|}{ Education } \\
\hline Diploma & 57 & 18.0 \\
\hline Degree & 249 & 78.8 \\
\hline Master & 9 & 2.8 \\
\hline $\mathrm{PhD}$ & 1 & 0.3 \\
\hline \multicolumn{3}{|l|}{ Status } \\
\hline Diploma & 57 & 18.0 \\
\hline Degree & 249 & 78.8 \\
\hline
\end{tabular}




\begin{tabular}{|c|c|c|}
\hline Master & 9 & 2.8 \\
\hline $\mathrm{PhD}$ & 1 & 0.3 \\
\hline \multicolumn{3}{|l|}{ Job Sector } \\
\hline Part Time study & 12 & 3.8 \\
\hline Full Time Study & 266 & 84.2 \\
\hline Private & 23 & 7.3 \\
\hline Self Employed & 8 & 2.5 \\
\hline Part Time job & 7 & 2.2 \\
\hline \multicolumn{3}{|l|}{ Mother 's Job } \\
\hline Accountant & 1 & 0.3 \\
\hline Business Management & 5 & 1.6 \\
\hline Doctor & 1 & 0.3 \\
\hline Lecturer & 1 & 0.3 \\
\hline Nurse & 3 & 0.9 \\
\hline Senior Assistant & 10 & 3.2 \\
\hline Teacher & 56 & 17.7 \\
\hline Others & 71 & 22.5 \\
\hline None & 168 & 53.2 \\
\hline \multicolumn{3}{|l|}{ Father's Job } \\
\hline Architect & 2 & 0.6 \\
\hline Businessman & 26 & 8.2 \\
\hline Doctor & 2 & 0.6 \\
\hline Engineer & 10 & 3.2 \\
\hline Farmer & 15 & 4.7 \\
\hline Fisherman & 2 & 0.6 \\
\hline HOD & 2 & 0.6 \\
\hline Lecturer & 3 & 0.9 \\
\hline Nurse & 1 & 0.3 \\
\hline Police Officer & 5 & 1.6 \\
\hline Teacher & 33 & 10.4 \\
\hline Others & 146 & 46.2 \\
\hline None & 69 & 21.8 \\
\hline \multicolumn{3}{|l|}{ Parent's Income } \\
\hline Less than RM1000 & 60 & 19.0 \\
\hline RM1000-RM3000 & 124 & 39.2 \\
\hline RM3000-RM5000 & 53 & 16.8 \\
\hline RM5000-RM7000 & 29 & 9.2 \\
\hline$>$ RM7000 & 41 & 13.0 \\
\hline None & 9 & 2.8 \\
\hline
\end{tabular}

Table 1 presents the demographic variables of the study which includes gender, state, year of study, semester, nationality, living place, age, education, status, job sector, mother's job, father's job, and parents' income. It is reported that about $222(70.3 \%)$ of the respondents are female while there were $94(29.7 \%)$ males. The data collection was also distributed across several universities in Malaysia. Approximately 124 (39.2\%) of the total respondents are from UMK, followed by $49(15.5 \%)$ from UITM and 61 (19.3\%) from UUM. Meanwhile the remaining respondents were from UPNM, 33 (10.4\%), UNISZA 15 (4.7\%), UPM $9(2.8 \%)$, UPSI 6 (1.9\%), UNIMAP 5 (1.6\%), USIM 5 (1.6\%), UMT $3(0.9 \%)$, UMP $2(0.6 \%)$, UTM 2 $(0.6 \%)$, UMS $1(0.3 \%)$ and UNIMAS $1(0.3 \%)$. Over half of the respondents, $197(62.3 \%)$, are in the first year of their studies, followed by 65 (20.6\%) of them who are in their second year, 
$38(12 \%)$ are in their third year and $16(5.1 \%)$ are in their fourth year. In terms of semester of the study, approximately $127(40.2 \%)$ are in their second semester, followed by $102(32.3 \%)$ who are in their first semester, $24(7.6 \%)$ are in their third semester, $23(7.3 \%)$ are in their fourth and sixth semester, $12(3.8 \%)$ are in their fifth semester and $3(0.7 \%)$ and $2(0.6 \%)$ are in their seventh and eighth semester.

All 316 respondents $(100 \%)$ are Malaysian, while for the aspect of living area, it is accumulated that $173(54.7 \%)$ of the respondents live in rural areas, and $143(45.3 \%)$ of the students stay in urban areas. By studying the religion of the respondents, a large number of the respondents were Muslim; 300 (94.9\%) while the remaining are followers of Hindu $7(2.2 \%)$, Christian $6(1.9 \%)$ and Buddha $3(0.9 \%)$. Over half of the respondents, $198(62.7 \%)$ are in the age range of 21-25 years, followed by $101(32 \%)$ who are $18-20$ years old and $17(5.4 \%)$ are 26-30 years old. In the aspect of education, more than three quarters of the respondents, 249 $(78.8 \%)$ are degree holders, followed by $57(18 \%)$ who are diploma holders, $9(2.8 \%)$ are master students and only $1(0.3 \%)$ is a $\mathrm{PhD}$ student.

By looking at the job sector, the majority of the respondents; $266(84.2 \%)$ are full time students, followed by $23(7.3 \%)$ who work in the private sector, $12(3.8 \%)$ are part time students, $8(2.5 \%)$ are self-employed and $7(2.2 \%)$ have a part time job. In analysing the mother's occupation, it is found that more than half of the respondents; $168(53.2 \%)$ of their mothers are housewives while the remaining are teachers $56(17.7 \%)$, senior assistants 10 $(3.2 \%)$, doing business $5(1.6 \%)$, nurse $3(0.9 \%)$, and $1(0.3 \%)$ is an accountant, doctor and lecturer respectively. It is shown that most of mothers are housewives, and it would seem that students should get a well and balanced family support system especially in organizing online learning.

In addition, this study also analyses the type of job of students' fathers. About 146 $(46.2 \%)$ of the students chose the item 'other'. That shows that their fathers have an occupation that is not listed in the demographic profile. Furthermore, about $69(21.8 \%)$ of their fathers are unemployed, and this could affect students' well-being. It is indisputable that a pandemic contributes to a huge amount people around the world being laid off from work. Whereas for occupations, it is recorded that $33(10.4 \%)$ of students' fathers work as teachers. While 26 $(8.2 \%)$ of them are businessmen, $15(4.7 \%)$ are farmers and $10(3.2 \%)$ are engineers. The rest are police officers; $5(1.6 \%)$, and lecturers; $3(0.9 \%)$. It is highlighted that some of the students whose parents are unemployed should be supervised to avoid other related problems such as depression and anxiety. It is suggested that educators should take the problems of students into account so that they are able to endeavour the ordeal during the pandemic of COVID- 19.

For the aspect of parents' monthly income, about $124(39.2 \%)$ of the parents earn between RM1000-RM3000, followed by 60 (19\%) who acquire less than RM1000, $53(16.8 \%)$ earn RM3000-RM5000, 41 (13\%) earn over RM7000, 29 (9.2\%) earned RM5000-RM 7000 and $9(2.8 \%)$ have no income. It would appear that students come from various backgrounds, and it should be emphasized that more than half of the parents possess an income of below RM 3000 , which needs further consideration in receiving social and financial support.

\section{Normality Test for Constructs}

The Normality test has been conducted to examine the distribution of the data. In order to comply with normality assumption, analysis skewness and kurtosis has been employed. According to Garson (2012), the data is considered normal if the value of skewness and kurtosis ranged between -2 to 2 . 
Table 2. The value of Normality.

\begin{tabular}{lcccccc}
\hline Construct & $\begin{array}{c}\text { Skewness } \\
\text { Stats }\end{array}$ & SE & $\begin{array}{c}\text { Kurtosis } \\
\text { Stats }\end{array}$ & SE & Mean & SD \\
\hline Physical Aspect & -0.21 & 0.14 & 0.12 & 0.27 & 4.94 & 0.98 \\
Emotional Aspect & -1.10 & 0.14 & 1.22 & 0.27 & 4.28 & 0.99 \\
Spiritual Aspect & -0.78 & 0.14 & 0.42 & 0.27 & 5.40 & 0.94 \\
Adaptability & -0.50 & 0.14 & -0.50 & 0.27 & 4.91 & 1.30 \\
\hline
\end{tabular}

Table 2 demonstrates that the value of skewness ranged between -1.10 to -0.21 while kurtosis ranges between -0.30 to 1.22 . It indicates that the value falls within the recommended range. It can be concluded that the data is normally distributed. In addition, there are three constructs in the current study which focuses on the physical, emotional, and spiritual aspect in measuring the adaptability of students during online learning. Table 3 presents mean and standard deviation of each construct. As shown, the mean and standard deviation for the physical aspect is $(4.94 \pm 0.98)$, whereas the emotional aspect is $(4.28 \pm 0.99)$, and the spiritual aspect is $(5.40 \pm 0.94)$. While the construct of adaptability is $(4.91 \pm 1.30)$ which are considered as acceptable ranges to measure the related items as discussed before.

The usage of mean score is to identify the average values of the items, and this shows that every item in each element is reliable, and it indicates that the participants agree with the statements related to each domain. In addition, if the mean is greater than 3.66, it means that the level of respondents' perception about certain aspect is high (Najihah et al. 2018). Thus, it is proven that students agree that the aspect of physical, emotional, and spiritual contributes to their adaptability in online learning. Table 3 will illustrate the statistical value which shows that most of the students agree with the statements of related items, and this would appear that these constructs will assist students' adaptability during online learning.

Table 3. Construct Validity and Reliability.

\begin{tabular}{lccc}
\hline & Cronbach Alpha & Composite Reliability & $\begin{array}{c}\text { Average Variance } \\
\text { Extracted (AVE) }\end{array}$ \\
\hline Emotional & 0.953 & 0.961 & 0.78 \\
Physical & 0.879 & 0.906 & 0.583 \\
Spiritual & 0.863 & 0.901 & 0.647 \\
Adaptability & 0.913 & 0.931 & 0.66 \\
\hline
\end{tabular}

Table 3 describes the values of construct validity and reliability of each domain. It is recommended that Cronbach Alpha (CA), Composite Reliability (CR) and Average Variance Extracted (AVE) should be more than 0.7 so that it will attain the satisfactory convergent validity (Hair et al. 2014). From the table, it is shown that every construct has achieved an acceptable valid range. Thus, the current study reveals that the three components are imperative to develop students' adaptability in online learning.

\section{DISCUSSION}

From the findings, it can be affirmed that it is crucial to identify students' adaptability during online learning because it hugely contributes to their well-being. Furthermore, the findings show that students believe the three components are essential in order to adapt well to an online environment. The current study also reveals that physical aspect such as the ability to 
participate in online learning plays a significant role in students being able to achieve learning goals. Students mention that they are able to obtain beneficial information from online lessons. Students are also required to adapt to related information that could help them understand elearning materials. Additionally, students also mention that there are several educators who still teach using conventional techniques. Hence, educators are also encouraged to explore new learning methods in order to produce a quality online learning experience. This also concerns the aspect of learning sources, students' activity as well as assessment techniques.

Other than that, the current study shows that learners' adaptability is highly associated with the components of physical, emotional, and spiritual in adapting virtual lesson. This is in line with the findings of (Baticulon et al. 2020) who mention that the essential skill and motivation aspect are important factors to adapt well in online learning. Other than that, another study also mentions that the components of adaptability for students' achievement include motivation, achievement, social and emotional well-being (Holliman et al. 2021).

For the aspect of students' data coverage, it is advised that learners should acquire sufficient internet support when attending online learning sessions. This is proven from the high level of mean which indicates students strongly agree that the three aspects are significant in promoting their adaptability during online lesson. It appears that two-way communication between educators and students is essential in determining whether some students live in rural areas where they cannot obtain adequate internet coverage. Thus, lecturers should spend some time with students in order for learners to be able to share problems with educators.

The current study also identifies several items that can be used to evaluate how students face the hardship of the pandemic of COVID-19. Additionally, a previous study also states that numerous students face mental health issues especially during panic-gogy (Aleksander et al. 2020). Hence, the current study highlights several essential items that can be used to measure the condition of students particularly in online learning.

For example, the current study reveals that even though they are unable meet their friends physically, students indicate that it is important to enjoy online learning. This element is important to reduce emotional problems among students. In addition, it is understood that early preparation could also help students adapt well to online lessons. This aspect will guide students to solve problems that they encounter before starting an online class. It will also assist students to gain the motivation they need to take in online learning.

Furthermore, this study also proves that the three constructs are essential elements to avoid students experiencing depression and anxiety particularly during online learning. Apart from a sophisticated e-learning system, it is critical to assess the situation of students whether they could handle the pressure of the new-norm, particularly in educational organizations. It is suggested to highlight other virtuous values that students need to practice to ensure they obtain a meaningful lesson in online learning. One uniqueness of identifying students' adaptability during online learning is the aspect of spirituality. The current study finds that students acknowledge the significance of reciting prayers before attending class. This is as a concept of soul preparation to invite inner peacefulness during online classes.

Additionally, students also admit that allocating time for study and religious activities is essential to developing strong adaptability during online lessons. This practise is a process of self-development because having a balance of the two is essential for the sustainability of the learning process. Besides, spiritual performance contributes to the attitude of consistency among students, thus it aids in building inner strength to face hardships in daily life. Moreover, Islam encourages Muslims to perform compulsory prayers because it will keep them away from performing evil actions (Al-Quran 29: 45). It would appear that the aspect of spirituality is a contributor to students' adaptability, especially in online learning, during the pandemic of COVID-19. 
From the discussion, it could be seen that understanding the main components of students' adaptability in online learning such as physical, emotional, and spiritual aspects could help students and educators to produce a high-quality online learning process. Other than that, it should be emphasised that educators should be committed to their students and play the important role of guiding them so that the needs of students are catered to. In addition, teaching in Islam encompasses the knowledge both inside and outside the learning session. This is an effort to instil good behaviour (akhlaq), a healthy lifestyle, moral values, strong faith, and a positive attitude among students (Kamal 2018).

\section{CONCLUSION}

This study concludes that a systematic and holistic approach should be taken into account among practitioners to increase teaching and learning quality. The items in the current study have been validated and it is suggested to expand the components towards all students whether in public universities or any other educational institutions. It is also understood that students need to possess a balanced well-being in order to reduce any other related problems such as depression and anxiety among students. It is proposed that this study could be one of the useful sources in enhancing the quality of online learning. The current study will also be broadened to evaluate the values and improved characteristics that students gain from their learning experience.

\section{REFERENCES}

Abdul Rashid, A., Amin Al Haadi, S., Umi, H., Raja Nur Syafiqah, R.A. 2020. Strategi Pembangunan Aspek Kesejahteraan Kendiri bagi Mendepani Tekanan Akademik Semasa Wabak COVID-19, Malaysian Journal of Social Scences and Humanities (MJSSH), 5(12): 16-30.

Aleksander, A., Damijana, K., Dejan, R., Nina, T., Lan, U. 2020. Impacts of the COVID-19 Pandemic on Life of Higher Education Students: A Global Perspective, Sustainability, 12, doi:10.3390/su12208438, 1-34.

Allan, M., Naomy, K.L., Tebatso, N., Md Mirajur, R.S. 2021. The Impact of Online Learning on International Students' Studies Amid the Covid-19 Pandemic During the 2020 Spring Semester: A Case Study of Southwest University, Asian Journal of Education and e-Learning (ISSN: 2321 - 2454), 9(1): 16-35.

Anya, K. 2020. 'Panic-gogy': Teaching Online Classes During the Coronavirus Pandemic. Special Series the Coronavirus Crisis, https:/www.npr.org/2020/03/19/817885991/panic-gogy-teaching-online-classesduring-the-coronavirus-pandemic. [accessed on July $5^{\text {th }}, 2021$ ].

Ateerah, A.R., Lukman, Z.M. 2019. Happiness Instrument Development, International Journal of Research and Innovation in Social Science, 3(4): 288-292.

Baticulon, R. E., Alberto, N. R. I., Baron, M. B. C., Mabulay, R. E. C., Rizada, L. G. T., Sy, J. J., Tiu, C. J. S., Clarion, C. A., and Reyes, J. C. B. 2020. Barriers to online learning in the time of COVID-19: A national survey of medical students in the Philippines," MedRxiv, 1-19, DOI: 10.1101/2020.07.16.20155747, preprint.

Brian, B. 2021. P-Value, Investopedia, (May 14, 2021), https://www.investopedia.com/terms/p/p-value.asp, accessed on September $20^{\text {th }}, 2021$. 
Camelia, M.R., Elena, S. 2021. Adaptability to Online Teaching during Covid-19 Pandemic: A Multiple Mediation Analysis Based on Kolb's Theory, International Journal of Environmental Research and Public Health, 18(8032):1-13.

Çebi, A., \& Güyer, T. 2020. Students' Interaction Patterns in Different Online Learning Activities and their Relationship with Motivation, Self-regulated Learning Strategy and Learning Performance, Education and Information Technologies, 1-19.

Daud, N., Norwani, N. M., \& Yusof, R. 2018. Students Financial Problems in Higher Education Institutions. International Journal of Academic Research in Business and Social Sciences, 8(10): 1558-1565.

Enik, S., Fitria, W., Moch, B.U., Hendra, E.R., Ika, S. 2018. Using Online Learning Systems to Measure Students' Basic Teaching Skill, International Journal of Engineering \& Technology, 7 (4.7): 463-467.

Ety, N.I. (2015). Peran Komunikasi dalam Interaksi Guru dan Siswa, Jurnal Al-Ta'dib, $8(2): 150-167$.

Fitarahmawati \& Suhartini. 2020. Empowering Critical Thinking and Problem-Solving Skills During Pandemic Through Contextual Distance-Learning in Biology, Proceedings of the 6th International Seminar on Science Education (ISSE 2020), Advances in Social Science, Education and Humanities Research, 541: 39-47.

Florence M., Brandy S., and Claudia, F. 2020. Examining Student Perception of Readiness for Online Learning: Importance and Confidence, Online Learning Journal, 24:(2): 38-58.

Flynn, G., \& Himel, J. 2020. School Closures Highlight Inequality in Education as Classes Move Online, Cambodianess. https://cambodianess.com/article/school-closureshighlight-inequality-ineducation-as-classes-move-online.

Garson, G.D. 2012. Testing Statistical Assumptions. Statistical Associates Publishing.

Holliman, A., Waldeck, D., Jay, B., Murphy, S., Atkinson, E., Collie, J., et al. 2021. Adaptability and social support: examining links with psychological wellbeing among UK students and non-students. Front. Psychol. 12:636520. doi: 10.3389/fpsyg. 2021.636520

Ilpi, Z. 2018. Learning Al-Islam and Kemuhammadiyahan in College Muhammadiyah, Advances in Social Science, Education and Humanities Research, Non-Formal Education International Conference (NFEIC 2018), 293:38-41.

Indira, D., Sakshi, M.S. 2017. Online Learning, International Education \& Research Journal, (IERJ), 3(8): 32-34.

Jalli, N. 2020. Lack of internet access in Southeast Asia poses challenges for students to study online amid COVID-19 pandemic. The Conversation. https://theconversation.com/lack-of-internet-access-in-southeast-asiaposes-challengesfor-students-to-study-online-amid-covid-19-pandemic133787

Joshi, A., Kale, S., Chandel, S., Pal, D.K. 2015. Likert Scale: Explored and Explained, British Journal of Applied Science \& Technology, 7(4): 396-403, ISSN: 2231-0843

Kacper, N., Anna, L., Jakub, Z., Monika, N., Anna, S. 2021. The Effectiveness of the Blended Learning in Conservative Dentistry with Endodontics on the Basis of the Survey among 4th-Year Students during the COVID-19 Pandemic, International Journal of Environmental Research and Public Health, 18, 4555.

Kainat, A., Muhammad, A. 2020. Online Learning amid the COVID-19 Pandemic: Students Perspectives, Journal of Pedagogical Research, 1(2):45-51, DOI:10.33902/JPSP.2020261309.

Kamal, J.B., Abdul Shakour, P., Che Noraini, Hashim. Nik Md Saiful, A. 2018. The Concept of Murabbi in Muslim Education with Reference to Selected Teaching Methods of The Prophet Muhammad (s.a.w). Al-Shajarah (Special Issue), International Islamic University of Malaysia. 327-357. 
Koçoğlu, E., Tekdal, D. 2020. Analysis of Distance Education Activities Conducted During Covid-19 Pandemic, Educational Research and Reviews, 15:536-543. DOI: https://doi.org/10.5897/ERR2020.4033.

Laksmi, M., Choi Chi, H., Leo, H., Agus, P., Masduki, A., Priyono, B. (2020). Teachers' Empowerment, Self-Regulation and being Istiqamah as Key Features of Job Performance, Available Online: https://dinastipub.org/DIJEMSS, 1(4): 468-478.

Ma, H.; Miller, C. 2020. Trapped in a Double Bind: Chinese Overseas Student Anxiety during the COVID-19 Pandemic, Health Commun.

Mahirah, B. (2017). Evaluasi Belajar Peserta Didik (Siswa), Jurnal Idaarah, 1(2): 257-267.

Mariano, M.S. 2021. Marketing Mix Modeling Using PLS-SEM, Bootstrapping the Model Coefficients, Mathematics, 9, 1832, https://doi.org/10.3390/math9151832

Meşe, E. \& Sevilen, Ç. 2021. Factors Influencing EFL Students' Motivation in Online Learning: A Qualitative Case Study, Journal of Educational Technology and Online Learning, 4(1): 11-22.

Rapanta, C., Botturi, L., Goodyear, P. 2020. Online University Teaching During and After the Covid-19 Crisis: Refocusing Teacher Presence and Learning Activity. Post-digit Science Education, 2, 923-945. https://doi.org/10.1007/s42438-020-00155-y.

Minitab. 2016. What Are T Values and P Values in Statistics? (November 4, 2016). https://blog.minitab.com/en/statistics-and-quality-data-analysis/what-are-t-values-andp-values-in-statistics, accessed on September 20 2021.

Najihah, A.W., Hasan, H., Anas, M.Y., Fadzli, A., Omar, S.H.S. 2018. The Importance of Psychological and Educational Counseling from the Students' Perspective, International Journal of Academic Research in Business and Social Sciences, 8(4), EISSN: 2222-6990.

Nurul, Z., Fahdian, R. 2020. Analysis of Online Learning Implementation and Student Learning Activities in the Covid-19 Pandemic Era and Its Problems, Proceedings of the 1st International Conference on Character Education (ICCE 2020), 167-176.

Shivangi, D. 2020. Online Learning: A Panacea in the Time of COVID-19 Crisis, Journal of Educational Technology Systems, 49(1): 5-22.

Timmons, K., Cooper, A., Bozek, E. 2021. The Impacts of COVID-19 on Early Childhood Education: Capturing the Unique Challenges Associated with Remote Teaching and Learning in K-2. Early Childhood Education Journal, https://doi.org/10.1007/s10643021-01207-z.

Tuan, N. 2015. The Effectiveness of Online Learning: Beyond No Significant Difference and Future Horizons, MERLOT Journal of Online Learning and Teaching, 11(2): 309-319.

Umi, C., Kurnisar, Ermanovida, Norma, Juainah. 2021. Building Religious, Honesty, Discipline, and Student Curiosity Character through HOTS-based Online Civic Education Learning, Jurnal Civics: Media Kajian Kewarganegaraan, 18(1): 118-126, DOI. 10.21831/jc.v18i1.39088

Zakaria, M., Junaidah, H., Rosliza, B., Siti Jeslyn, H., Salwa, Z. 2021. Benefits and Challenges of Adopting Google Classroom in Malaysian University: Educators' Perspectives, Ilkogretim Online - Elementary Education Online, 20 (1):1296-1304, http://ilkogretimonline.org, doi: 10.17051/ilkonline.2021.01.123.

Zulvia, T., Rehani, Ratna, K., Riswandi. 2020. Implementation of Islamic Character Based Education in Students' Religious Extracurricular Activities, Jurnal Penelitian, 17(1): 95-106, DOI: https://doi.org/10.28918/jupe.v17i1.2650 
ATEERAH ABDUL RAZAK

Centre for Language Studies and Generic Development Universiti Malaysia Kelantan

16300, Bachok, Kelantan, MALAYSIA

NOOR HISHAM MD NAWI

Centre for Language Studies and Generic Development

Universiti Malaysia Kelantan

16300, Bachok, Kelantan, MALAYSIA

ASMA’ LAILEE MOHD NOOR

Centre for Language Studies and Generic Development Universiti Malaysia Kelantan

16300, Bachok, Kelantan, MALAYSIA

BURHAN CHE DAUD

Centre for Language Studies and Generic Development

Universiti Malaysia Kelantan

16300, Bachok, Kelantan, MALAYSIA

MARWAN ISMAIL

Centre for Language Studies and Generic Development

Universiti Malaysia Kelantan

16300, Bachok, Kelantan, MALAYSIA

*Corresponding author: ateerah@umk.edu.my

Received: 11 August 2021 / Accepted: 25 October 2021 / Published: 20 November 2021 